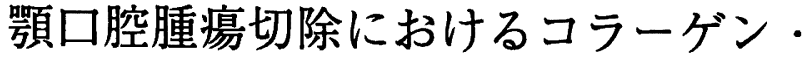 シリコン複合体人工粘膜の臨床応用に関する検討
}

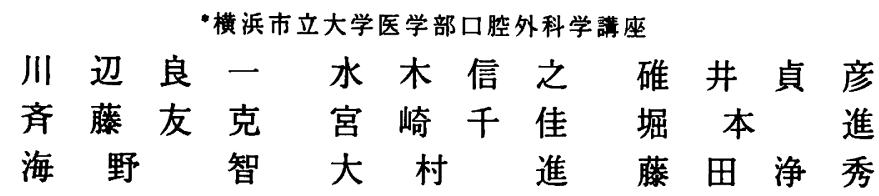

論文要旨

額口腔領域における腫場切除後の口腔粘膜欠損創に対して, 真皮欠損用グラフト (テルダーミス $\left.{ }^{\circledR}\right)$ が, 組 織再構筑型の永久移植材として有用であることを明らかにした。本材は, 生体内安定性に優れた線維化アテ ロコラーゲンと生体親和性に優れた熱変性アテロコラーゲンの複合物にシリコン膜を付与し，短時間熱脱水

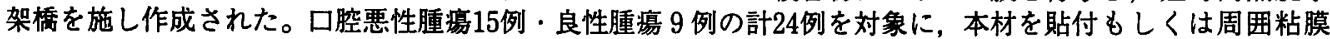
と䋖合した。その結果，骨・軟組織いずれの創部においても，操作性，止血・鎮痛効果，肉茅形成，上皮化 に優れ，拘縮の度合いも少なく，副作用もなく，人工粘膜としての機能を有した。

Key words : 人工生体材料（Biomaterials）, コラーゲン (Collagen), 創傷被覆材（Wound dressing)

\section{緒 言}

額口腔領域における腫場切除後の口腔粘膜欠損に対し ては, 創部の閉鎖や保膵を目的に, 従来より種々の生体 材料や人工材料の応用が試みられてきた ${ }^{1.3)}$ 。しかしなが ら，生体に対する親和性・安定性や操作性に関して，必 ずしも満足のゆく結果は得られていなかっだ。今回わ れわれは, 生体内安定性に優れた線維化アテロコラーゲ ンと, 生体親和性に優れた熱変性アテロコラーゲンの複 合物にシリコン膜を付与し，短時間熱脱水架橋を施した 真皮欠損用グラフト (テルターミス $\left.{ }^{\circledR}\right)$ を，額口腔腫瘍 切除後の欠損に対して用い，その有用性に関して検討し たので報告する。

\section{研究と対象方法}

対象症例は, 横浜市立大学医学部口腔外科における手 術症例24例であった。症例は12歳から77歳まで, 平均59 歳であり，性別は男性 9 例，女性15例であった。腫瘍は

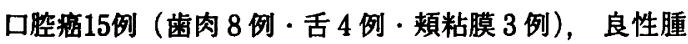
湟 9 例（小湩液腺多形性腺腫 3 例，エナメル上皮腫・工 プーリス各 2 例，神経線維腫・線維腫各 1 例）であった。 欠損の大きさは $150 \mathrm{~mm}^{2}$ から $6250 \mathrm{~mm}^{2}$ まで，創部の性 状としては主として骨創部が13例, 主として軟組織創部

別紙請求先 :

于 236 横浜市金沢区福浦 3-9

横浜市立大学医学部口㓐外科学請座 川辺良一
が 7 例，軟組織および骨の複合した創部を有する症例が 4 例であった。

今回用いたテルダーミス ${ }^{\circledR}$ (テルモ社) は, 抗原決定 基のテロペプチドを除去した, 牛皮间酵素可溶化アテロ コラーゲンを原料として, 線維化アテロコラーゲンと熟 変性アテロコラーゲンを $9: 1$ の割合で混合凍結乾燥し た層の上に厚さ $100 \mu \mathrm{m}$ のシリコン膜を付与し， 2 層化 したものを熱脱水架橋して作成された。無菌製品化され た大きさ $50 \times 25 \mathrm{~mm}$ ，厚さ $6 \mathrm{~mm}$ の材型のものを用い た (図 1$)$ 。

欠損部位への適用方法としては, 腫場切除後の創部に 応じて本材料の大きさを調整し, 軟組織創部の症例に対 しては周囲粘膜と縫合した。骨創部の症例に対しては本 材の密着性によりそのまま貼付するか, もしくは周囲組 織と縫合し，さらに症例によってはプラスチック製保䘫 床を使用した。また大きな欠損に関しては本材を複数個 使用した。創部が骨から軟組織におよぶ場合は, 症例に 応じて複数の本材を個々の創部に適用,もしくは一材に て同時に被覆した。

有用性の検討においては, 手術時の操作性および術後 の止血効果 · 密着度 - 鎮痛効果 - 肉芽形成 ·上皮化 - 感 染・拘縮に関して評価した。

\section{結果}

本材料は，貼付直後より止血効果を有して速やかに生 体組織と一体化し，表面のシリコン膜のみが術後 7 10 日目に自然脱落した。経過中に本材の脱落，感染は認め 


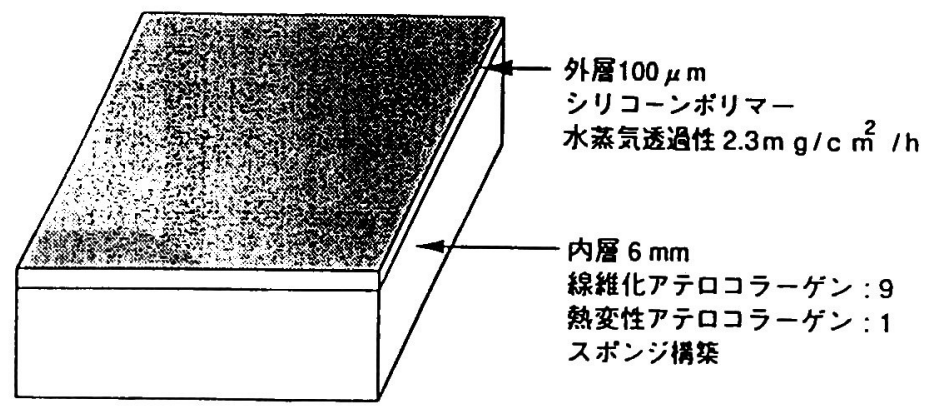

図 1 真皮欠損用グラフト(テルダーミス $\left.{ }^{\circledR}\right)$ の構造
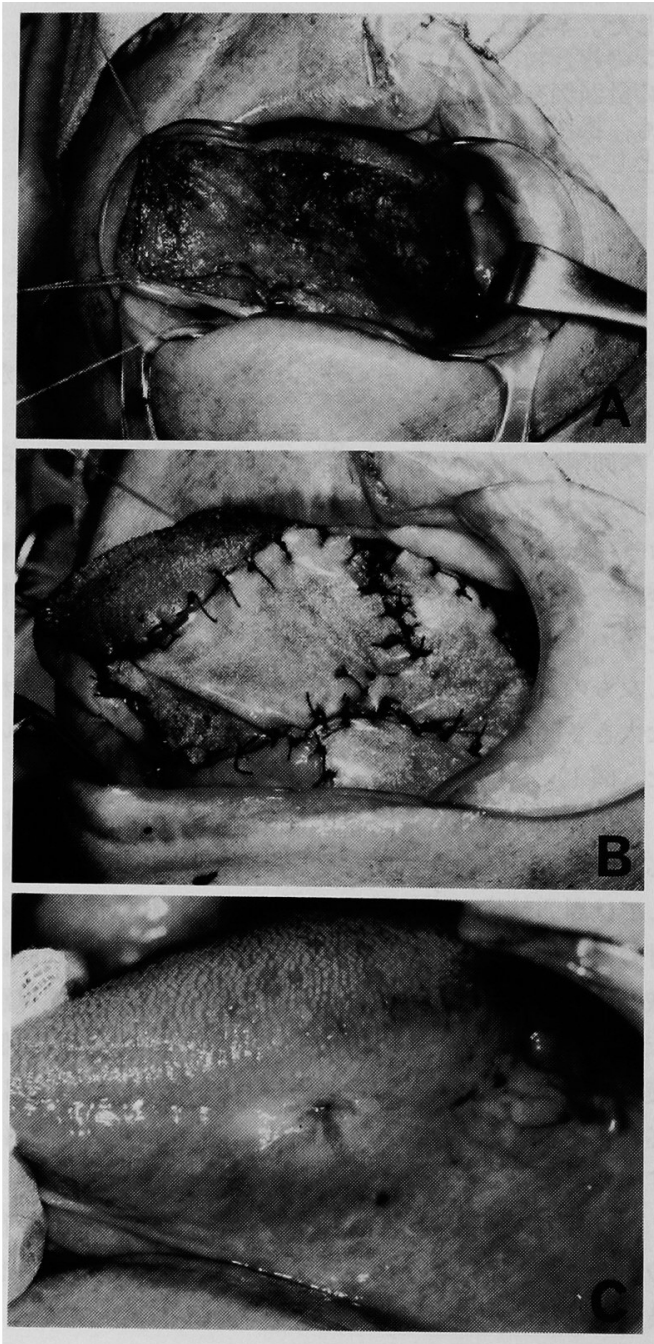

写真 1 舌癌症例

$A ：$ 広範な白板症を含め切除した創部

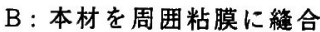

$\mathrm{C}:$ 術後 6 週の創部
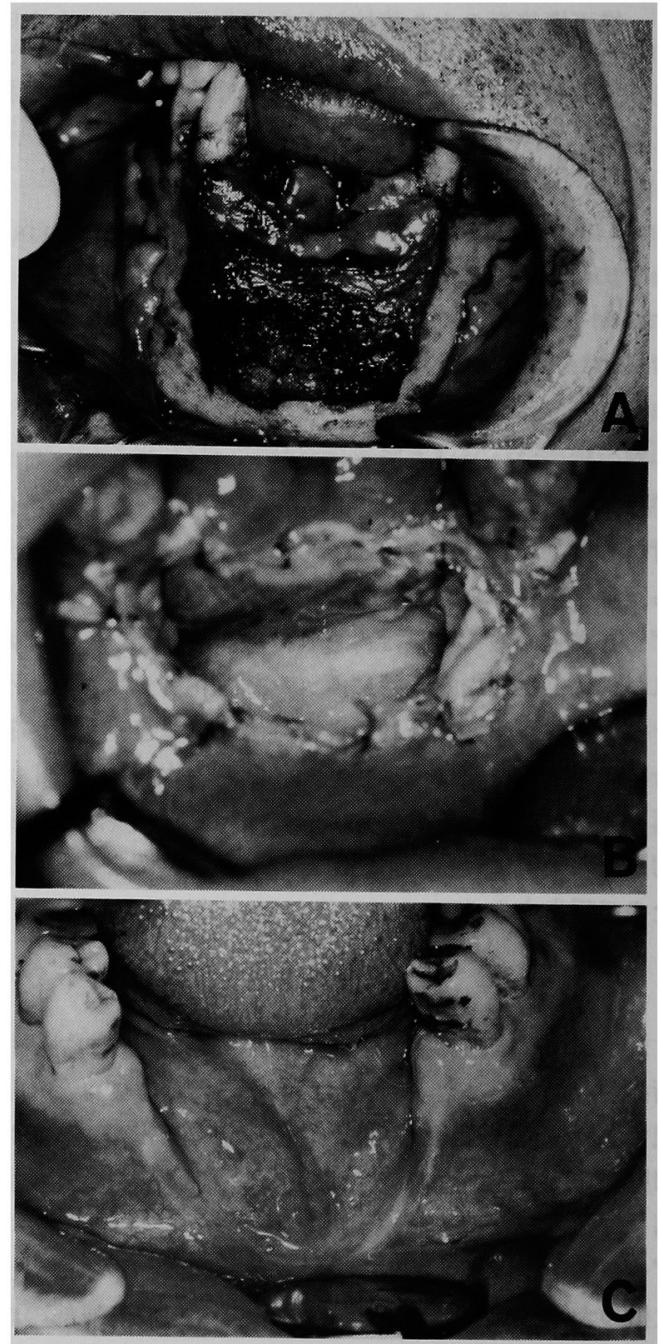

写真 2 エナメル上皮腫症例

$A$ : 切除時の創部

B : 本材貼付後 1 週の創部

C : 術後 8 週の創部 
られず，操作性 -止血効果・密着度・鎮痡効果に優れて いた。肉芽形成・上皮化も良好で, 拘縮の度合いも少な かった。また副作用は認められなかった。軟組織・骨い ずれの創部においても良好な結果が得られた。ただし広 箐囲の欠損は，小箅囲の欠損と比較すると，その中央部 での上皮化が遅く，軟組織創部においては痝痕拘縮の程 度も大きく，軽度の陥凹や白色線状の㴬痕を認める症例 も認められた。

ついで広範な創部を有する代表的な症例を供覧する。

症例 1 は74藏, 女性の舌早期浸潤癌症例で, 舌・口底 および一部左側額堤粘膜におよぶ白板症を伴っており， 切除時広範な粘膜欠損をきたした（写真 $1 \mathrm{~A})$ 。本材を 4 枚周囲粘膜と縫合し，また隣接する本材同士は stay suture を併用しながら綘合した（写真 1B）。術後出 血もなく疼痛も軽微であった。術後 1 週にてシリコーン 膜は剥離した。上皮化は良好で，6 週後には，その中央 に小宿凹が認められるが, 舌・口底部に可動性粘膜が獾 得され，舌の可動性は良好であった (写真 $1 \mathrm{C})$ 。

症例 2 は70歳, 男性の下影前歯部のエナメル上皮腫に 对する辺緑切除症例で, 二次症例にて粘膜欠損を余儀な くされ，頪舌側はオトガイ棘より上方の軟組織が，近遠 心側および下額下縁側には骨が露出した（写真 $2 \mathrm{~A}$ )。 本材 5 枚を, 軟組織創部では周囲粘膜・組織と縫合し, 骨創部には貼付後さらにプラスチック製栓塞子を装着し た。出血もなく，栓塞子着脱時の疼痛もなかった。術後 1 週目にはシリコーン膜のみが剥離してきた (写真 $2 \mathrm{~B}) 。$ 栓塞子を調整しつつ, 創の治瘾を図ったところ, 肉芽形 成・上皮化は良好で, 舌・口底拉よび口唇部の洀痕拘縮 をほとんど認めずに，義額装着に至った（写真 $2 \mathrm{C})$ 。

\section{考察}

額口腔領域の腫場切除・摘出後の広範な組織欠損に対 して, 生体組織特に自家各種組織の移植および人工材料 を用いた補填が行われる。この両者ともに近年その進歩 を遂げ形態ならびに機能の回復に貢献しており，その欠 損の形態・規模により粎々な選択ができるようになった 5)。しかしながら, 顥口腔腫場切除の特性として, 術前 治療の影響や合併症の他に，硬組織の処理，唾液，口腔 内細菌による創部の污染感染, 顎運動など, 治療法の選 択には配虑すべき点も多く，またその方法・材料にも改 善の余地がある。

従来よりコラーゲンを含め種々の人工材料の組織欠損 部への応用が試みられてきたが，いずれも一時的な創傷 被頮材にすぎなかった 高いテロペプチドを除去したアテロコラーゲンを原料と しているため, 従来の不溶性コラーゲンより抗原性が少 ない。またコラーゲンの性状が線維芽細胞の挙動に影響
を及ほすことから，物理的強度に優れ，分解醳素に対し て抵抗性を有する線維化コラーゲンと細胞の遊走性に優 れた熱変成コラーゲンの比率を考虑して，生体残存性が 高く細胞侵入性に優れるよう調整されている ${ }^{6,7)}$ 。また化 学架橋を施していないため貼付後に血液・浸出液を吸収 し, 早期にスポンジ構造からゲル構造になり，周囲より 線維芽細胞・毛細血管の侵入を促す ${ }^{7}$ 。早期に粘膜固有 層様組織になり，粘膜固有層・粘膜下層組織を量的に補 填し，本材は徐々に吸収されながら宿主の組織と置き換 わる。また本材の安全性は口腔粘膜欠損創 ${ }^{(8.11)}$ のみなら ず, 皮庯欠損創への臨床応用 ${ }^{12-14}$ においても支持されて いる。

靧口腔領域腫瘍切除の際には, 粘膜上皮由来の腫瘍は もとより，粘膜上皮由来の腫堭でなくとも，腫場の性状 . 部位により口腔粘膜の欠損を来すこともあり，その創傷 被覆材としては, 人工粘膜としての役割を果たすことが 要件である ${ }^{4.8)}$ 。

本材は上記コラーゲンの特長に加え，表層に付与され たシリコーン膜が, 外部からの細菌の侵入を防止し, 適 度な水蒸気透過性により疼痛感の減少や浸出液の漏出防 止の役割を果たす9。またシリコーン膜が剥離するにつ

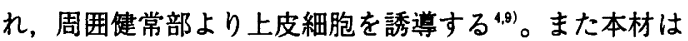
形態の調整が容易で，材料の形態や縫䌅を考虑した切開 線の設定が不要であり ${ }^{4,10)}$ ，術後管理も容易で，創部の 感染もなく早期の経口摂取の開始できる ${ }^{4.10)}$ などの利点 を有する。

創部の性状と被覆材料との関係をみると，骨創部に関 しては，遊離粘膜・皮席移植は生着不良であり，また従 来の人工材料では疼痛の緩和・上皮再生の促進などの効 果を有するものの，一時的な創傷被覆材である ${ }^{1-3)}$ のに対 して，本材は，固有層・粘膜下組織としての量的・質的 補填をはかる副と同時に，上皮化を誘導するため，人工 粘膜として, 優れた組織構築型の永久移植材と考える。

創部が軟組織に限られた場合においては，本材の使用 は，遊離皮局・粘膜移植に比して拘縮の度合いがやや大 きいが，その手技・術後管理は簡便である。またレーザー 蒸散法 ${ }^{16} に$ に比して, 創部との密着性を高めるための䋃合 に時間を要するが，拘縮の度合いに大差はなく、レーザー の使用が解剖学的に困難な部位での応用も可能である。 したがって，軟組織創部における本材の応用は，氺の 部位・範囲などにより選択する治療法の一つと考える。

創部が骨と軟組織におよぶ場合は，術後機能に最も関 与する部位であるが，本材にて簡便に被覆できる上，拘 縮などの機能障害の軽減を図れるため, 本材の利点が生 かせる。また腫怚切除と同時に，もしくは二期的に前庭 拡張術を簡便に行うことができ ${ }^{49)}$ ，さらに局所粘膜弁と の併用にて複雑な組織欠損の再建にも有効である゙など, 
本材は広く応用可能である。

以上より，本材は人工粘膜としての機能を有する組織 構築型の永久移植材であり, 安全性, 創の確実で迅速な 治瘜, 機能障害の軽減と形態の回復などの要件を満たす ことから, 顎口腔領域腫湟切除後の欠損への応用は有意 義と考える。

\section{結語}

顎口腔腫瘍切除後の口腔粘膜欠損創に対する真皮欠損 用グラフト (テルダーミス $\left.{ }^{\circledR}\right)$ の有用性に関して検討し た。

口腔内の骨・軟組織いずれの創部においても, 操作性, 止血 ·鎮痛効果, 肉芽形成, 上皮化に優れ, 拘縮の度合 いも少なく，副作用も認められなかったことから，本材 は組織再構築型の永久移植材として有用と考えた。

\section{引用文献}

1）金田敏郎, 柴田重雄 他: 委軟フィブリン膜のロ腔 手術への応用, 日口外誌 $19: 357-364,1973$.

2）金田敏郎，中条昭博他：創侮暫間被夏材 LPS (凍結乾燥豚皮) の口㓐外科手術への応用, 日口外 誌 $27: 132-141,1981$.

3）大月佳代子，大西正俊他：キチン創侮被夏保讙材 の口腔粘膜欠損部への臨床応用, 日口外誌 36 : 2103-2110, 1990.

4) 水木信之, 大村 進 他: コラーゲン・シリコーン 複合体人工粘膜の口腔粘膜欠損部への臨床応用に関 する検討，日ロ外誌 $40: 776-784,1994$.
5) 清水正品：口㓐癌切除後の預口腔の再建，清水正阔， 小浜源郁編, 口腔㿋, 初版, 348-365 頁, 1989, テ ンタルタイヤモンド社, 東京.

6) 大崎健一, 小西淳他：コラーゲンスポンジを用 いた新しい人工皮凮、人工䑏器 $18: 151-154,1989$.

7) 小西淳，後藤明久他：自己組織を再構筑させる 新タイプのコラーゲン材料, 人工䑏器 $18: 155-$ $158,1989$.

8) 水木信之, 川辺良一 他：コラーゲングラフト（2 層性人工皮成）の口埶粘膜欠損への臨床応用（抄）, 日口外誌 $38: 2054-2055,1992$.

9) 水木信之, 大村進 他：菌科・ 口㓐外科領域にお ける 2 居性人工粘膜（テルターミス®）の臨床使用 経験、ザ・クインテッセンス $13: 1532-1542,1994$.

10）杉山芳樹, 榎本昭二 他：真皮用グラフト（SS-D） の口腔粘膜欠損への使用経験，基䃈と臨床 28 : 244-254, 1994.

11）水木信之, 藤田浄秀: 真皮欠損用グラフト「テルダー ミス」を用いた口腔粘膜欠損層への臨床応用，デン タルマガジン $82: 28-31,1994$.

12）平山峻, 東山卓嗣他: 皮间久損用グラフト (SS-D) の臨床使用経験, Ther Res 13:319-331, 1992.

13）大浦武彦, 杉原平樹他：皮庙欠損用グラフト （SS-D）の臨床使用, Ther Res $13: 253-268,1992$.

14）石田寞友, 熊谷案夫他：皮间久損用グラフト （SS-D）を用いた臨床使用例の検討, 基礎と臨床 $26: 346-354,1992$.

15）大崎健一, 小西淳他：人工皮庙を用いた新しい 皮成再構成の試み, 人工䑏器 $20: 497-502,1991$.

16) Gaspar L. : The use of the high power lasers in oral surgery. Acta Biomed Ateneo Parmense 63 : 85$92,1992$. 


\title{
CLINICAL EVALUATION OF A NEW COLLAGEN SPONGE AND SILICONE BILAYER "ARTIFICIAL MUCUOS MEMBRANE" FOR THE RESECTION OF ORAL TUMORS
}

\author{
Ryoichi KAWABE, Nobuyuki MIZUKI, Sadahiko USUI, \\ Tomokatsu SAITO, Chika MIYAZAKI, Susumu HORIMOTO, \\ Satoshi UMINO, Susumu OMURA and Kiyohide FUJITA
}

Department of Oral and Maxillofacial Surgery, School of Medicine, Yokohama City University

A new bilayer artificial mucous membrane (TERUDERMIS ${ }^{\circledR}$, Terumo Co.) has been developed as a permanent material that promotes the reconstruction of tissue. It consists of a bottom layer of fibrillar collagen and heat-denatured collagen with dehydrothermal cross-linking, and an upper layer of a silicone elastomer.

We used this material successfully in the treatment of 24 patients in whom problems with the oral mucosa on the bone and/or soft tissue, had developed during the resection of oral tumors.

This materials was found to be easy to handle, adhere well and promote hemostasis, relieve pain, have little antigenicity, limit infection, promote rapid epithelialization, and produce newly connective tissue and with minimum contraction.

The results suggest that this material is safe and effective for clinical use. 